FACTA UNIVERSITATIS

Series: Mechanical Engineering Vol. 18, N ${ }^{\circ} 1,2020$, pp. $31-42$

https://doi.org/10.22190/FUME190623005B

Original scientific paper

\title{
SURFACE MODIFICATION OF RING-TRAVELER OF TEXTILE SPINNING MACHINE FOR SUBSTANTIALITY
}

\author{
Preetkanwal Singh Bains ${ }^{1}$, Jasmaninder Singh Grewal', \\ Sarabjeet Singh Sidhu ${ }^{1}$, Sandeep Kaur ${ }^{3}$, Gurpreet Singh ${ }^{1}$
}

${ }^{1}$ Department of Mechanical Engineering, BCET, Gurdaspur, Punjab, India ${ }^{2}$ GNDEC, Gill Road, Ludhiana, Punjab, India

${ }^{3}$ GNDU (RC), Gurdaspur, Punjab, India

\begin{abstract}
In this report, a study of the wear mechanisms involved in the spinning ring and the traveler of textile industry are presented. These components, after surface processing with various coatings techniques, were analyzed on the test rig so as to analyze the wear mechanism. The objective was accomplished by comparing various plasma sprayed coatings on E52100 steel pins using a pin-on-disc machine. The surface morphology as well as mechanical properties of the deposited coatings, namely WC-Co$\mathrm{Cr}, \mathrm{Al}_{2} \mathrm{O}_{3}+\mathrm{TiO}_{2}$ (Alumina-Titania) and $\mathrm{Cr}_{3} \mathrm{C}_{2} \mathrm{NiCr}$, as well as uncoated E52100, were comparatively studied. This study elucidates towards improving the working life of the ring in a textile mill in the spinning operation. An x-ray diffractometer (XRD) and scanning electron microscope (SEM) were employed to characterize the unworn and worn surfaces of the specimens. The study revealed that the wear rate of plasma sprayed thermal coatings enhanced with augmenting load. The plasma sprayed $\mathrm{WC}-\mathrm{Co}-\mathrm{Cr}$, $\mathrm{Cr}_{3} \mathrm{C}_{2} \mathrm{NiCr}, \mathrm{Al}_{2} \mathrm{O}_{3}+13 \mathrm{TiO}_{2}$ coatings developed on workpiece pins exhibited a notable decrease in volume loss of the material as compared to uncoated E52100 substrate. WC$\mathrm{Co}$-Cr coating turned out to be the best performer in terms of the lowest cumulative volume loss among all the variants of coatings.
\end{abstract}

Key Words: Pin-on-disc, Thermal, $\mathrm{Al}_{2} \mathrm{O}_{3}$, Coatings, SEM, Traveler, XRD, Ring

\section{INTRODUCTION}

The wear mechanisms amongst various parts of the spinning machine have been extensively studied and analyzed by myriad researchers over the past few years. For the efficient working of a textile mill, a ring and a traveler play a crucial role; the later impart twisting to yarn (thread), around the inner periphery of the ring, facilitating the winding

Received June 23, 2019 / Accepted January 11, 2020

Corresponding author: Sarabjeet Singh Sidhu

Department of Mechanical Engineering, Beant College of Engineering \& Technology, Gurdaspur - 143521, Punjab, India

E-mail: sarabjeetsidhu@yahoo.com 
of the yarn on the bobbin. The centrifugal force between the two generates a high pressure during winding when the traveler glides around the ring along with the yarn (Fig. 1). As a consequence, the inner surface of the ring deteriorates in the form of waviness depicting abnormal wear pattern. This problem, however, mushrooms in by the recurring high-temperature cycles in addition to the usual tribological contact between them. The waviness formation on the internal face of the ring interrupts the free sliding of the traveler along the ring, resulting in an irregular winding of the thread. The obstructed sliding motion is usually associated with abrasion and wears causing the uneven and rough internal surface of the ring. Owing to abrasive wear, this causes the affected part to fail prematurely and demands regular replacements and reinstating of the rings. Moreover, this causes a considerable breakage of the thread and hence results in reduction in production efficiency [1,2]. In the light of this, the surface modification of this component was carried out in this study, to enhance the compatibility, durability and performance with the help of suitable surface coatings.
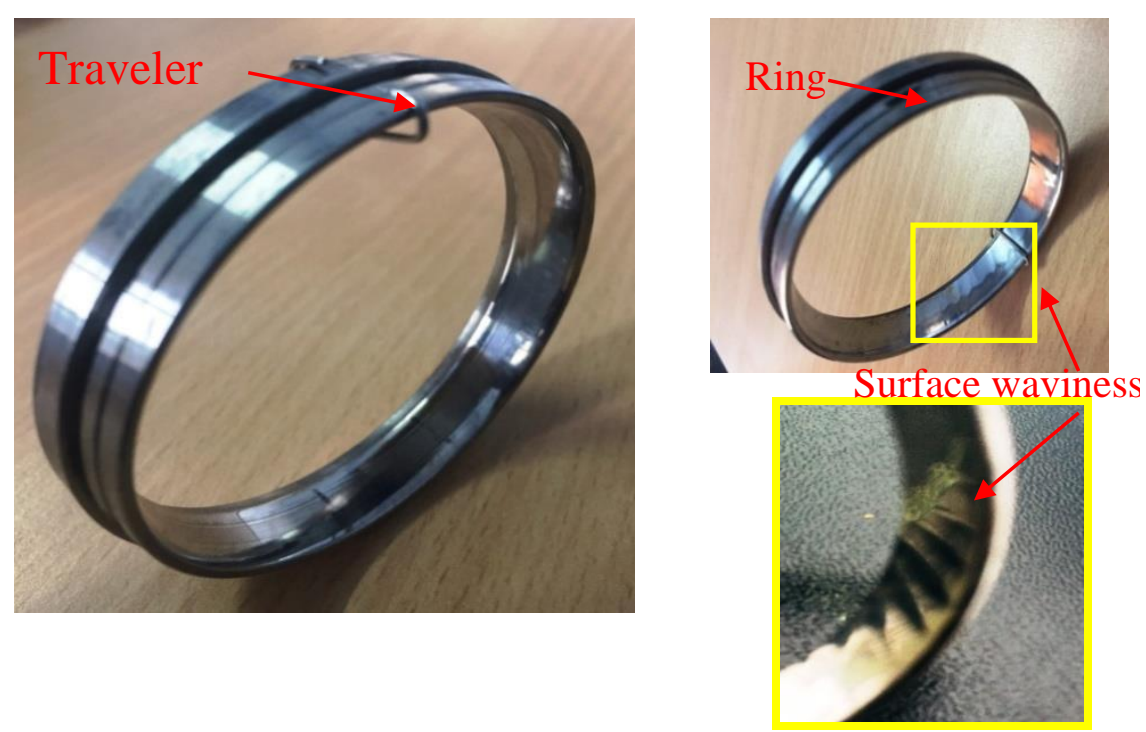

Fig. 1 New spinning Ring (left) and damaged Ring surface (right)

Ceramics possess infinite merits over metallic as well as polymeric materials and are known for high hardness and effective resistance to the thermal and corrosive environment [3,4]. Numerous oxide ceramics like alumina, silica, zirconia, titania, and chromium find widespread applications as potential materials for surface coatings and thermal barriers and for enhancing erosion, wear, abrasion, and corrosion resistance [5, 6]. Plasma spraying has been the prominent thermal deposition method in this regard [79]. When spraying for coating, the molten particles collide to build a layer of coating with superior thermo-mechanical properties. The coating is generated high energy collision of particles to form solidified layer. $\mathrm{Al}_{2} \mathrm{O}_{3}$ and $\mathrm{Cr}_{2} \mathrm{O}_{3}$ coatings have been a point of interest for several industrial applications like turbines and pumps [10]. $\mathrm{Al}_{2} \mathrm{O}_{3}$ is a ceramic material known to have exceptional resistance to wear along with exhibiting high 
hardness at elevated temperatures $[11,12]$. It has been witnessed from literature study that $\mathrm{Cr}_{2} \mathrm{O}_{3}$ coating is a better candidate for a wear and erosion resistant coating in a gentle sliding condition, under the normal load and it may exhibit typical tribological behavior. Rickerby and Winstone [13] put forward that the surface coatings help to deal with the physical and chemical degradation of the surface. The fracture toughness of $\mathrm{Al}_{2} \mathrm{O}_{3}$ coatings can be enhanced by the addition of $\mathrm{TiO}_{2}$ particles clad in the form of layers [14]. Thermal spraying is an effective and economical route to develop thick and uniform coatings for the surface modification of a part [15]. These spray coatings techniques are extensively used in automobile, textile, turbines, and aircraft industry [16]. The investigations revealed that the properties of the coatings primarily depend on the cohesion/bonding of particles which varies steeply with the temperature of sprayed particles [17]. Although copious research work [18-21] associated with the wear resistant coatings developed by plasma spray and HVOF techniques could be witnessed, much less work towards improving the wear resistance of distinct components of the textile industry has been traced. In $\mathrm{Cr}_{3} \mathrm{C}_{2} \mathrm{NiCr}$ coating, the $\mathrm{NiCr}$ phase is responsible for the required corrosion resistance whereas the carbide ceramic phase provides the necessary abrasive wear resistance [22, 23].

This study, thus, aims at exploring the characteristics and wear behavior of plasma sprayed coated E52100 pins using WC-Co- $\mathrm{Cr}, \mathrm{Al}_{2} \mathrm{O}_{3}+\mathrm{TiO}_{2}$ and $\mathrm{Cr}_{3} \mathrm{C}_{2} \mathrm{NiCr}$ ceramics. The wear trends of coating observed from these tests were used to envisage the working life of the actual rings in the textile mill.

\section{MATERIALS AND METHODS}

\subsection{Preparation of substrate and coating deposition}

Usually, the rings in the spinning machine are mainly subjected to friction and abrasive wear [24]; thus, to overcome such problems, WC-Co-Cr, $\mathrm{Al}_{2} \mathrm{O}_{3}+13 \mathrm{TiO}_{2}$ and $\mathrm{Cr}_{3} \mathrm{C}_{2} \mathrm{NiCr}$ [25] opt as coating materials. The detail of the coating powders utilized in the present work is enlisted (Table 1) as below. Sulzer-Metco F4 plasma gun for atmospheric plasma spraying is employed to deposit three coating variants. Argon as carrier gas acts as a medium for both plasma-operation and coating powders.

Table 1 Detail of the plasma sprayed powders

\begin{tabular}{lccccc}
\hline Powder & Preparation Route & $\begin{array}{c}\text { Powder size } \\
(\mu \mathrm{m})\end{array}$ & $\begin{array}{c}\text { Density } \\
\left(\mathrm{mg} / \mathrm{mm}^{3}\right)\end{array}$ & $\begin{array}{c}\text { Shape of } \\
\text { particles }\end{array}$ & $\begin{array}{c}\text { Composition } \\
(\text { wt. \% })\end{array}$ \\
\hline $\mathrm{WC}-\mathrm{Co}-\mathrm{Cr}$ & Sintering/Agglomerated & $-45 /+10$ & 5.8 & Spherical & $86 \mathrm{WC}, 10 \mathrm{Co}, 4 \mathrm{Cr}$ \\
$\mathrm{Al}_{2} \mathrm{O}_{3}+13 \mathrm{TiO}_{2}$ & Blending & $-45 /+11$ & 3.43 & Angular & $87 \mathrm{Al}_{2} \mathrm{O}_{3}, 13 \mathrm{TiO}_{2}$ \\
$\mathrm{Cr}_{3} \mathrm{C}_{2} \mathrm{NiCr}$ & Cladding & $-45 /+15$ & 3.0 & Irregular & $85 \mathrm{Cr}_{3} \mathrm{C}_{2}, 15 \mathrm{NiCr}$ \\
\hline
\end{tabular}

A high-carbon iron alloy, E52100, in the form of pins (50mm x 5mm) was used as a substrate material owing to its hardenability and resistance towards wear, making it suitable for industrial applications. $\mathrm{Al}_{2} \mathrm{O}_{3}+13 \mathrm{TiO}_{2}$, WC-Co- $\mathrm{Cr}$ and $\mathrm{Cr}_{3} \mathrm{C}_{2} \mathrm{NiCr}$ powders were deposited with a thickness in the range of $100-150 \mu \mathrm{m}$ on the end-faces of the E52100 substrate (Fig. 2) material by the plasma spray. Nine circular specimens $(50 \mathrm{~mm}$ of length, $5 \mathrm{~mm}$ diameter) were grit blasted using alumina grits at $3 \mathrm{~kg} / \mathrm{cm}^{2}$ pressure. The stand-off distance in shot blasting was kept between $150-200 \mathrm{~mm}$. The average roughness of the surface to be coated was fixed as $6.8 \mu \mathrm{m}$ (approx.) facilitating suitable adhesion of 
the sprayed particles. The grit blasted specimens were cleaned with acetone in an ultrasonic cleaning unit followed by spraying. The chemical composition of the material used for testing (E52100) has been represented in Table 2.

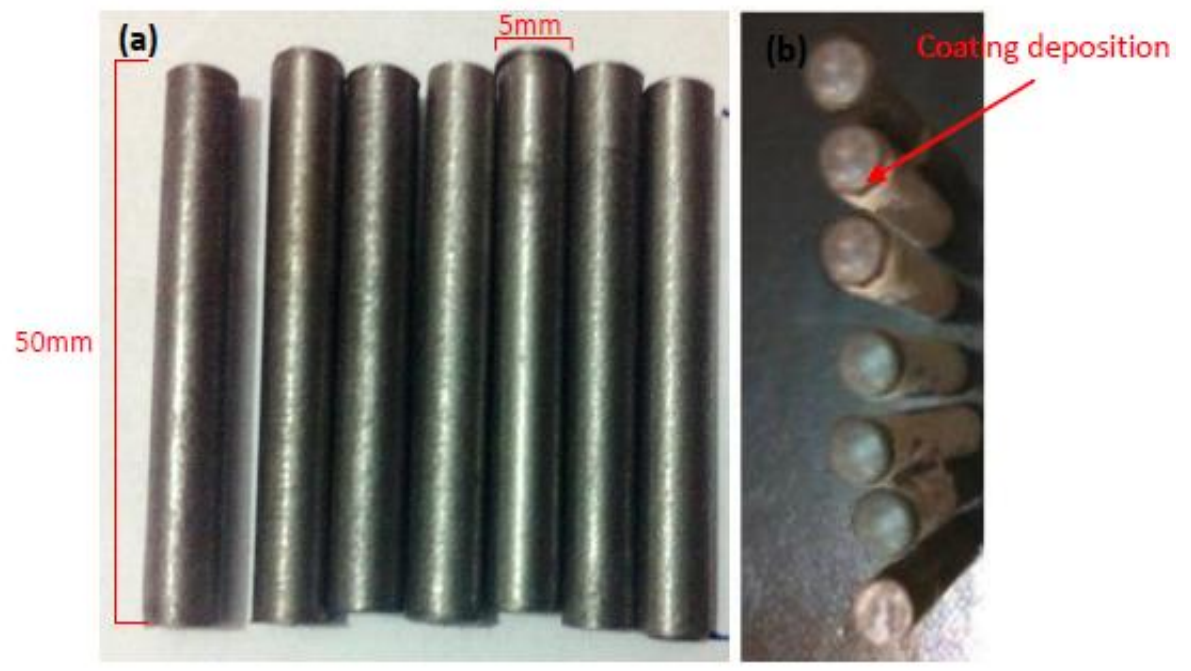

Fig. 2 Pictorial view of (a) Pins; (b) As-coated pin ends

Table 2 Chemical composition of E52100 pins

\begin{tabular}{ccccccccc}
\hline Grade & \multicolumn{10}{c}{ Elements (\%) } \\
\hline \multirow{2}{*}{ E52100 } & $\mathrm{Cr}$ & $\mathrm{C}$ & $\mathrm{Ni}$ & $\mathrm{Si}$ & $\mathrm{Cu}$ & $\mathrm{P}$ & $\mathrm{Mn}$ & $\mathrm{S}$ \\
\cline { 2 - 9 } & 1.580 & 0.996 & 0.107 & 0.236 & 0.11 & 0.054 & 0.468 & 0.005 \\
\hline
\end{tabular}

\subsection{Characterization of microstructure}

The microstructures and surface morphologies of the coating powder were examined using (JSM 6610LV, JEOL) field emission scanning electron microscopy (FE-SEM). In order to obtain coatings of uniform thickness, the same was noted precisely during the procedure of plasma spraying using a thin film thickness gauge (Minitest-600B, precision $\pm 1 \mu \mathrm{m})$ at six distinct points, considering the average thickness of the coating. To identify distinct phases, XRD analysis for coated specimens was carried out using the X'Pert PRO, Panalytical Advance Diffractometer (Netherland) with $\mathrm{CuK}_{\alpha}$ radiation and nickel filter at $40 \mathrm{~mA}$. The SEM examination of the coated samples before the wear test was carried out showing the dense, even with few pores and proper deposition of coatings without unmelted particles, as shown in Fig. 3. 

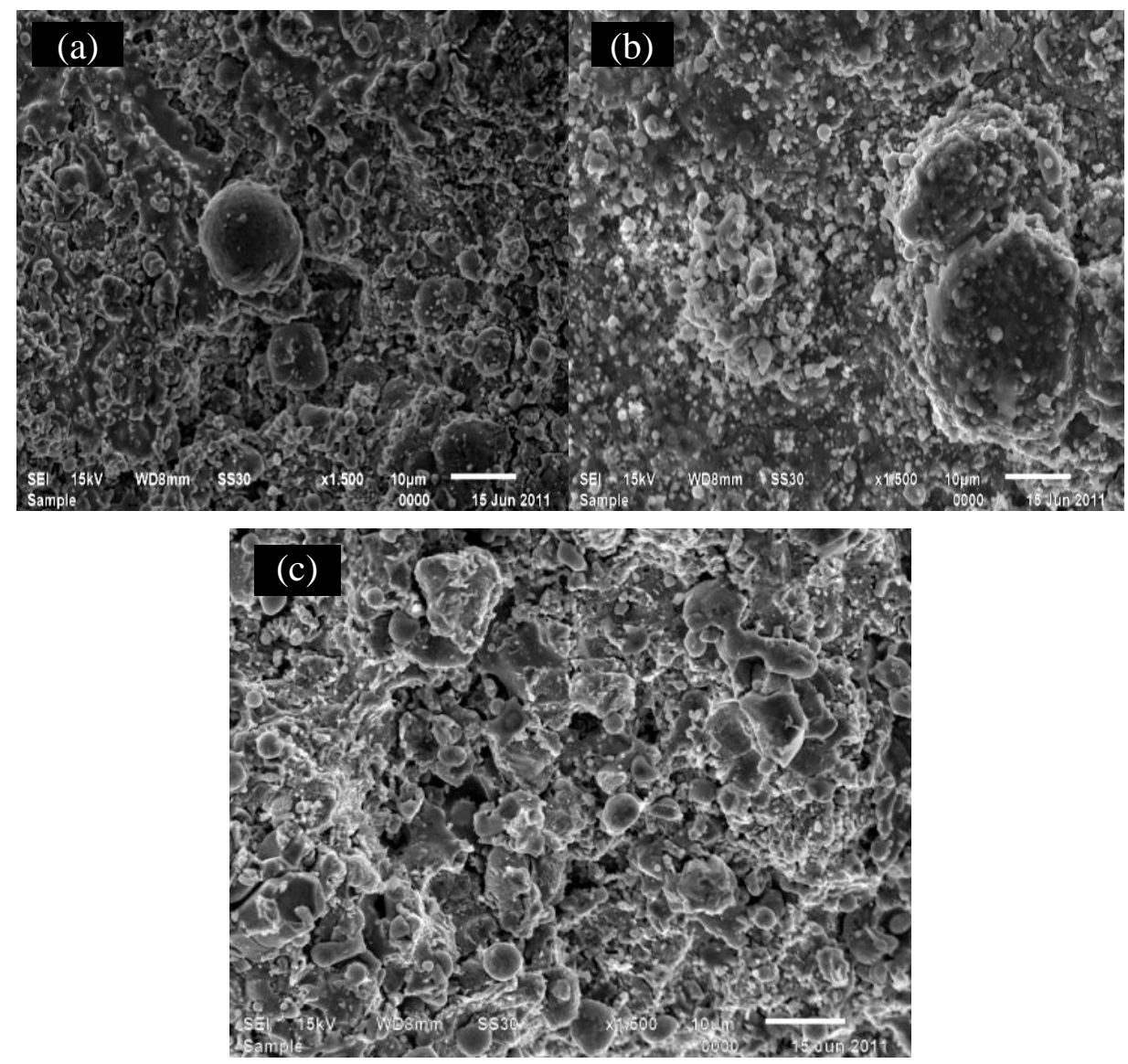

Fig. 3 Morphology of as-coated specimens: (a) WC-Co-Cr; (b) $\mathrm{Al}_{2} \mathrm{O}_{3}+13 \mathrm{TiO}_{2}$; (c) $\mathrm{Cr}_{3} \mathrm{C}_{2} \mathrm{NiCr}$

\subsection{Experimental procedure}

To examine the controlled wear, the comparative tests were carried out for uncoated and plasma sprayed cylindrical pins (E52100) by employing a pin-on-disc apparatus (wear and friction monitor, TR-201) (Fig. 4) that incorporates a rotating disc and a sample holder loaded with dead weights. The weights $(30 \mathrm{~N}, 40 \mathrm{~N}, 50 \mathrm{~N})$ were applied as a normal force on the sample for 30 minutes. The specimen pin was fixed in the holder at $80 \mathrm{~mm}$ track diameter with the coated end facing the carbon steel (EN-31) rotating disc of a hardness of 64 HRC. The parameters of wear test are presented in the Table 3.

The specimens were cleaned and degreased and weighed using a precision electronic balance (Citizen, CY220). The loss of weight for each specimen was noted at a gap of 30 minutes. After each trial, the sample pin was allowed to cool at room temperature after removing from the test rig. The wear debris was removed with the help of brushing, the sample was re-weighed to determine the material loss and then fixed back in the holder in the same position. 


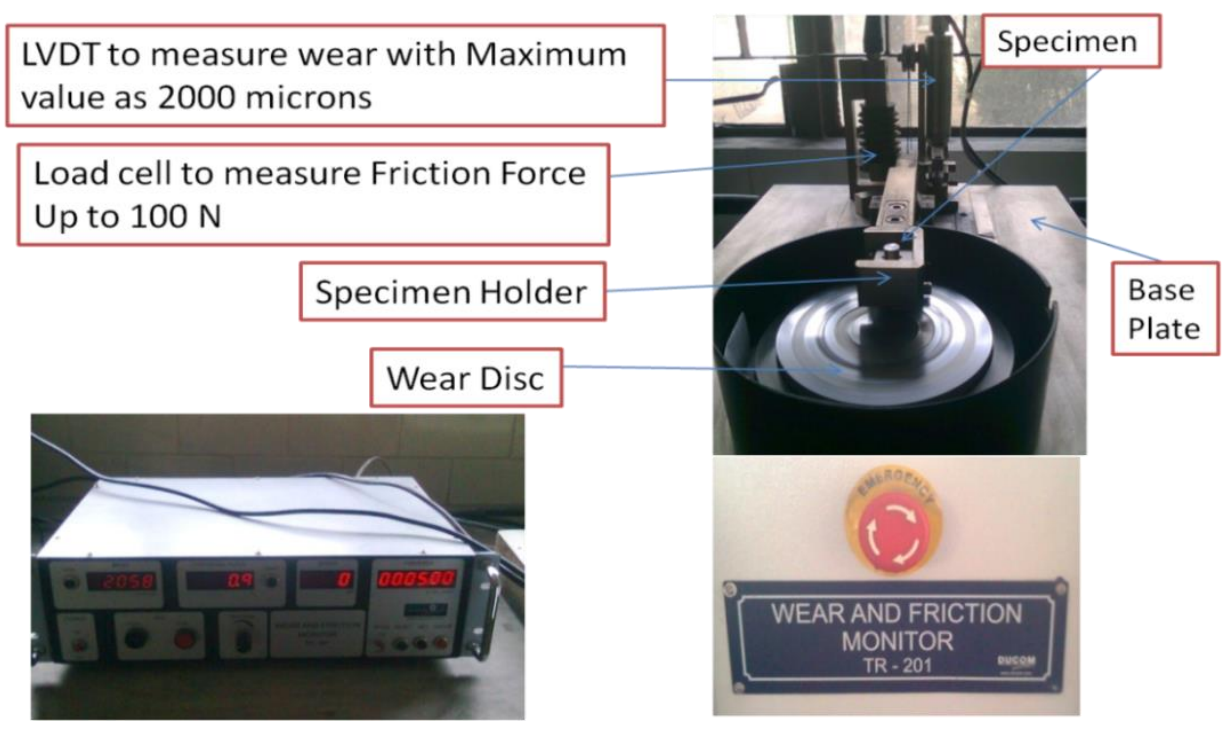

Fig. 4 Pin-on-disc wear apparatus

Table 3 Parameters of the sliding wear test

\begin{tabular}{ll}
\hline Nomenclature & Value \\
\hline Pin diameter $(\mathrm{mm})$ & 5.0 \\
Pin material & E52100 Bearing alloy steel \\
Disc material & Carbon steel (EN 31) \\
Track diameter $(\mathrm{mm})$ & 80 \\
Velocity $(\mathrm{m} / \mathrm{s})$ & 5.50 \\
Sliding distance $(\mathrm{m})$ & 5400 \\
Weight $(\mathrm{N})$ & $30,40,50$ \\
\hline
\end{tabular}

Additionally, the volume loss represented in Table 4 indicates the amount of wear encountered by each sample calculated according to below Eq. (1),

$$
\operatorname{CVL}\left(\mathrm{mm}^{3}\right)=\frac{\text { weight loss }(\mathrm{mg})}{\text { density of coating material }\left(\mathrm{mg} / \mathrm{mm}^{3}\right)}
$$

The density of the coating material was measured by the gravimetric method. Moreover, the average porosity of as-sprayed coatings was less than $1 \%$. The average thickness of selected coatings was recorded as 125 microns (approx) as measured using Minitest-600B. Fig. 6 shows the microstructure of the worn out surfaces of the coated specimens. Typical X-ray diffractograms (Fig. 7) for plasma sprayed coatings on E52100 specimens were carried out for phase identification with a rate of scanning ranging from $1^{\circ}$ to $100 \% \mathrm{~min}$ (2Theta) with $\mathrm{Cu}-\mathrm{K} \alpha$ radiation equals to $1.5418 \AA$. 
Table 4 Experimentation design and results

\begin{tabular}{|c|c|c|c|c|c|}
\hline \multirow{2}{*}{ Trials } & \multirow{2}{*}{ Coatings } & \multirow{2}{*}{ Load } & \multicolumn{2}{|c|}{$\operatorname{CVL}\left(\mathrm{mm}^{3}\right)$} & \multirow{2}{*}{$\begin{array}{c}\text { S/N Ratio } \\
(\mathrm{dB})\end{array}$} \\
\hline & & & R1 & $\mathrm{R} 2$ & \\
\hline 1 & WC-Co-Cr & 30 & 0.059 & 0.061 & 24.4358 \\
\hline 2 & WC-Co-Cr & 40 & 0.048 & 0.052 & 26.0137 \\
\hline 3 & WC-Co-Cr & 50 & 0.090 & 0.101 & 20.3856 \\
\hline 4 & $\mathrm{Al}_{2} \mathrm{O}_{3}+13 \mathrm{TiO}_{2}$ & 30 & 0.084 & 0.084 & 21.5144 \\
\hline 5 & $\mathrm{Al}_{2} \mathrm{O}_{3}+13 \mathrm{TiO}_{2}$ & 40 & 0.083 & 0.086 & 21.4615 \\
\hline 6 & $\mathrm{Al}_{2} \mathrm{O}_{3}+13 \mathrm{TiO}_{2}$ & 50 & 0.099 & 0.111 & 19.5621 \\
\hline 7 & $\mathrm{Cr}_{3} \mathrm{C}_{2} \mathrm{NiCr}$ & 30 & 0.300 & 0.299 & 10.4721 \\
\hline 8 & $\mathrm{Cr}_{3} \mathrm{C}_{2} \mathrm{NiCr}$ & 40 & 0.665 & 0.665 & 3.5436 \\
\hline 9 & $\mathrm{Cr}_{3} \mathrm{C}_{2} \mathrm{NiCr}$ & 50 & 0.528 & 0.531 & 5.5226 \\
\hline
\end{tabular}

In order to draw valid conclusions, the prominent process factors, for instance, coating type and load (Table 4) selected by screening trials were changed at three levels. The limited numbers of runs were achieved as the optimum conditions using the full factorial design. In this experiment, two different repetitions at random order were carried out to obtain the $\mathrm{S} / \mathrm{N}$ ratio for more precise results. The $\mathrm{S} / \mathrm{N}$ ratio is considered as a performance measure in terms of ratio of magnitude of the signal strength to the noise.

\section{RESULTS AND DISCUSSION}

The input variables chosen according to the control $\log$ of the standard full factorial method, and the recorded cumulative volume loss (CVL) values for wear of coatings along with their respective $\mathrm{S} / \mathrm{N}$ ratio are arranged in Table 4. It is noteworthy from Fig. 5 that the coating is the most significant parameter affecting the volume loss of the coated samples; wherein, WC-Co-Cr coated pin (sample) exhibited very less wear damage. However, the severe abrasive wear was witnessed for $\mathrm{Cr}_{3} \mathrm{C}_{2} \mathrm{NiCr}$ variant of coating sample and was severe amid all the selected variants of coatings. Moreover, the load applied during the pin-on-disc testing was observed as an insignificant factor affecting the wear of the coated surface (Table 5). Hence, the wear resistance of plasma sprayed coatings generated on E52100 substrate was recorded as WC-Co-Cr $>\mathrm{Al}_{2} \mathrm{O}_{3}+13 \mathrm{TiO}_{2}>\mathrm{Cr}_{3} \mathrm{C}_{2} \mathrm{NiCr}$ in their decreasing order.

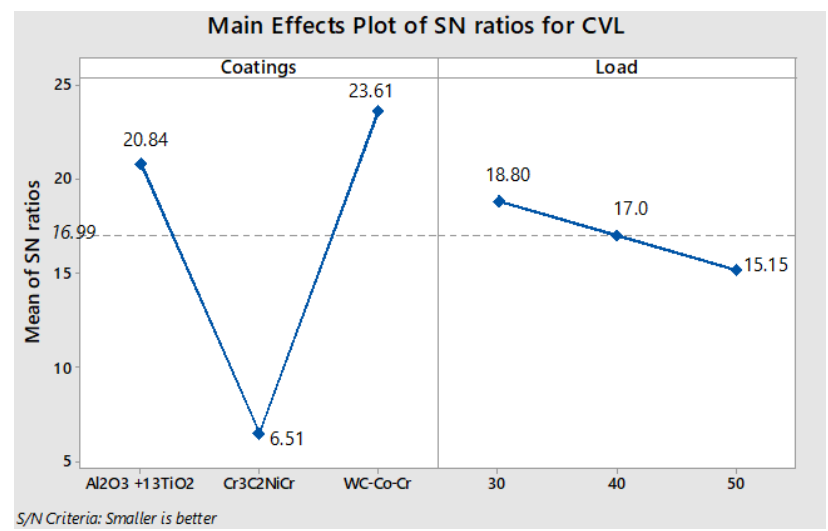

Fig. 5 Main effects plot of $\mathrm{S} / \mathrm{N}$ ratios for $\mathrm{CVL}$ 
Table 5 Analysis of variance for CVL

\begin{tabular}{lcrcrcc}
\hline Source & DF & Seq SS & Adj SS & Adj MS & F-value & p-value \\
\hline Coatings & 2 & 505.46 & 505.46 & 252.736 & 40.75 & $0.002^{*}$ \\
Load (N) & 2 & 19.99 & 19.99 & 9.996 & 1.61 & 0.307 \\
Residual Error & 4 & 24.81 & 24.81 & 6.203 & & \\
Total & 8 & 550.27 & & & & \\
\hline \multicolumn{7}{c}{ *significant }
\end{tabular}

The post-wear characterization of SEM micrographs of worn samples in Fig. 6 shows that the surface deposition remained uniform, homogeneous entailing no visible cracks. Fig. 6(a) illustrates that mostly spherical shaped particles were present with an elongated profile in few particulates resulting in denser coatings. The traces of carbide fragmentation followed by spalling were observed from Fig. 6(a). Some debris containing partially molten particles of the agglomerated and sintered alumina-titania had been noticed, as shown in Fig. 6(b). Also, SEM
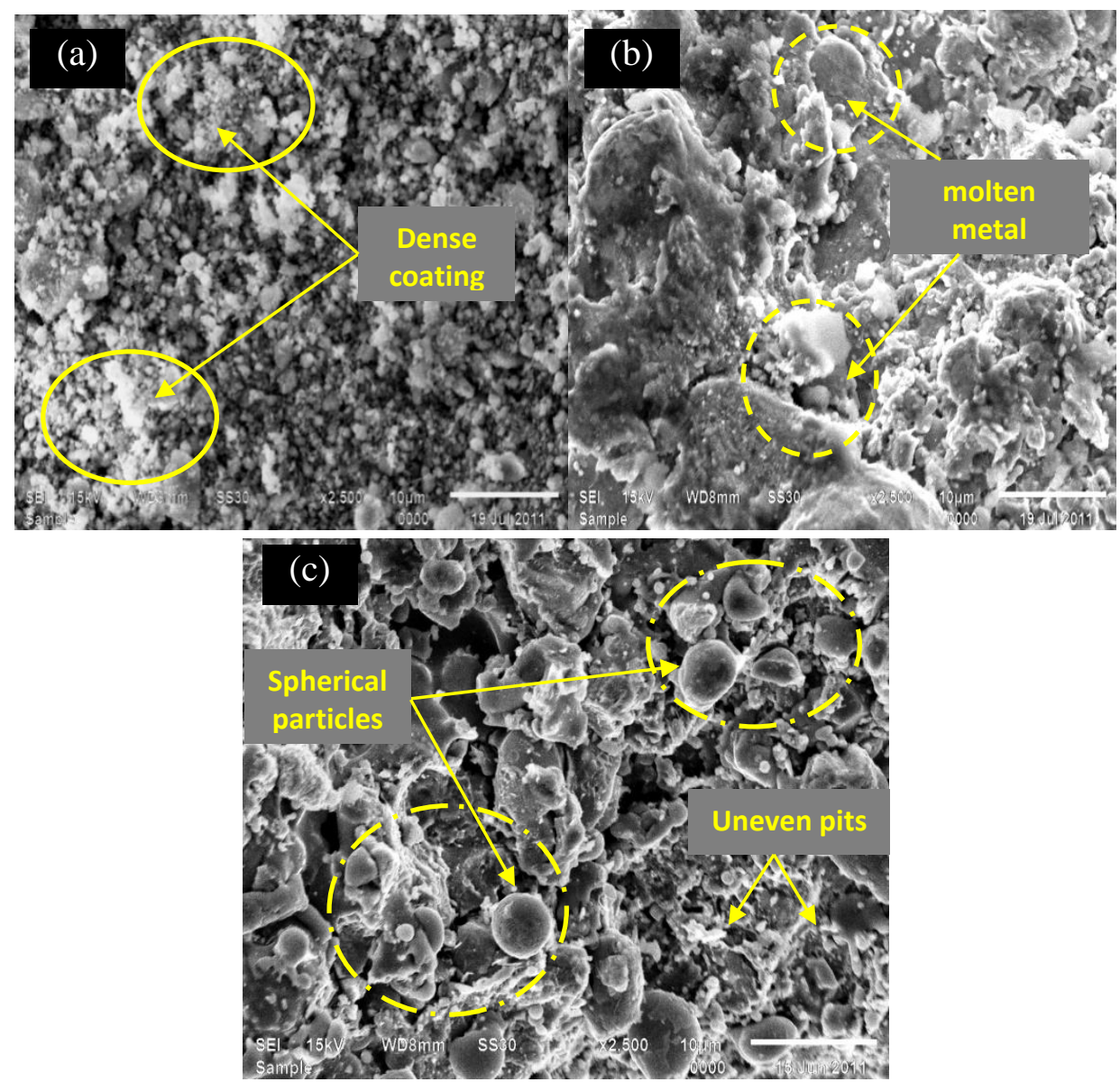

Fig. $6 \mathrm{SEM}$ of worn samples (a) WC-Co-Cr (b) $\mathrm{Al}_{2} \mathrm{O}_{3}+13 \mathrm{TiO}_{2}(\mathrm{c}) \mathrm{Cr}_{3} \mathrm{C}_{2} \mathrm{NiCr}$ (at $30 \mathrm{~N}$ ) 
micrographs revealed that oxidation might have occurred due to the presence of $\gamma-\mathrm{Al}_{2} \mathrm{O}_{3}$, as disclosed in XRD analysis (Fig. 7). However, in Fig. 6(c) white layers revealing that stress concentration were more prominent in the $\mathrm{Cr}_{3} \mathrm{C}_{2} \mathrm{NiCr}$ variant of coating, exhibiting minimum resistance for abrasive wear amid all coatings. The wear mechanism has impacted the $\mathrm{Cr}_{3} \mathrm{C}_{2} \mathrm{NiCr}$ coating surface in form of uneven pits as a sign of brittle fracture accompanied by small and non-uniform plastically deformed region. A significant grain fracture and subsurface damage were witnessed in WC-Co-Cr coated specimen.

The assessment of worn surface using X-ray diffraction measurements was carried out to analyze the surface modification of specimens. The XRD images depicted a notable quantity of WC as the major constituent phase which resulted in increased hardness of the coating, besides $\mathrm{Cr}$ and $\mathrm{Co}$ as a minor fraction in WC-Co-Cr coating. This ruled out any possibility of decarburization of $\mathrm{WC}$ as a result of $\mathrm{Cr}$ addition during coating procedure as no other phase, as expected, was spotted, which could be attributed to the chromium addition [26, 27]. Additionally, certain spectrum peaks showed an evident quantity of retained cobalt as a binder phase. X-ray diffractogram of $\mathrm{Al}_{2} \mathrm{O}_{3}+13 \mathrm{TiO}_{2}$ coating specified the occurrence of the broad bulge between $45^{\circ}$ and $65^{\circ}$ in the concerned pattern that promoted the development of an amorphous phase. Few peaks for rutile- $\mathrm{TiO}_{2}(6 \%$ wt. fraction) could also be witnessed in X-ray analysis (Fig. 7). The X-ray diffractogram in Fig. 7 signified a high content of $\gamma-\mathrm{Al}_{2} \mathrm{O}_{3}$ accompanied by almost equal amounts of $\mathrm{TiO}_{2}$ along with a small amount of amorphous; $\mathrm{Al}_{2} \mathrm{O}_{3}$ attributed to the rapid solidification of molten particles of alumina $[28,29]$. The $\mathrm{X}$-ray diffractogram for $\mathrm{Cr}_{3} \mathrm{C}_{2} \mathrm{NiCr}$ advocated a higher amount of chromium carbide as the major phase. $\mathrm{NiCr}$ compound has been detected as a minor phase in the form of a small one.

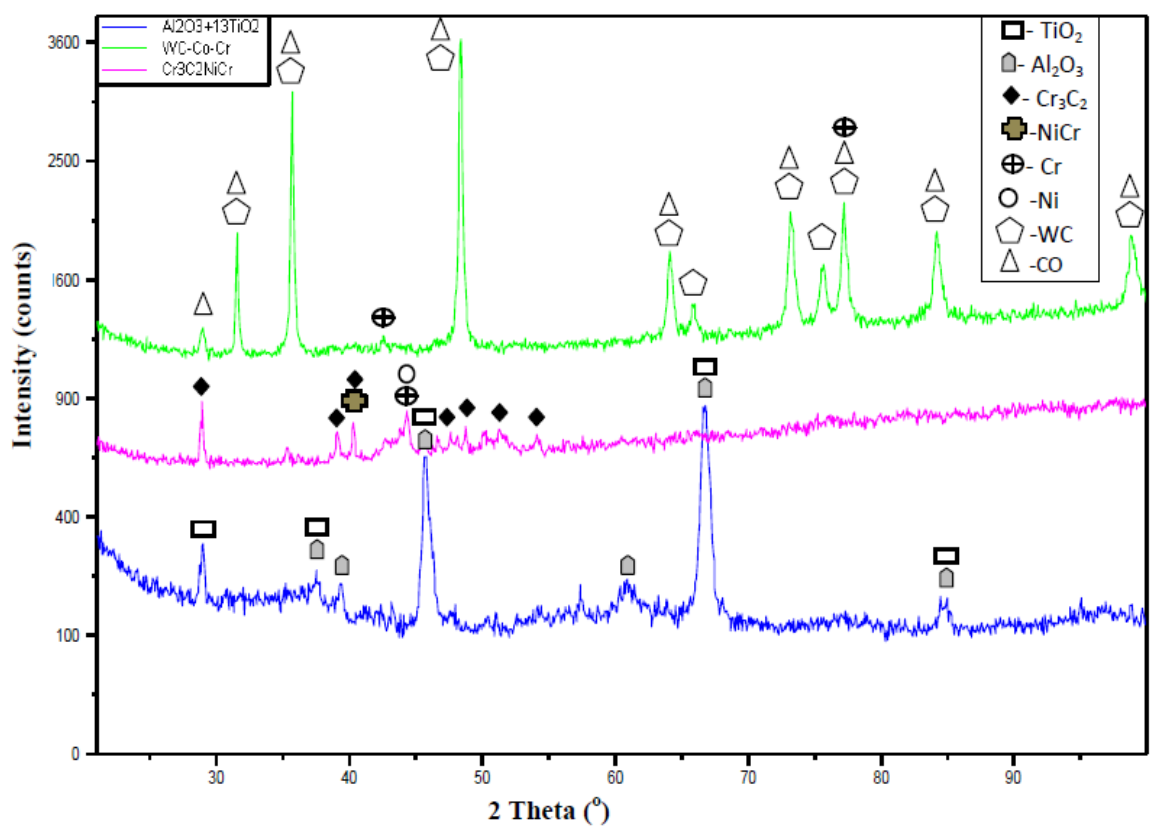

Fig. 7 XRD spectra for coated E52100 samples after wear 
Three coated specimens with each coating were analyzed against wear on pin-on-disc apparatus with normal acting loads ranging between $30 \mathrm{~N}, 40 \mathrm{~N}$ and $50 \mathrm{~N}$, respectively (Table 4) along with uncoated specimen of E52100 substrate. Fig. 8 depicts the wear resistance of all the three variants of plasma sprayed coatings. Furthermore, the rate of wear for $\mathrm{Cr}_{3} \mathrm{C}_{2} \mathrm{NiCr}$ coating augmented with normal load whereas WC-Co-Cr coating showed a negligible effect.

The uncoated pins of E52100 exhibited CVL of 5.660, 7.245 and $6.904 \mathrm{~mm}^{3}$ at load of 30,40 and $50 \mathrm{~N}$, respectively. The wear resistance of coating with tungsten carbide powder is recorded to be higher amid all coatings. This is due to a relatively high amount of wear resistant fused carbide powder in this variant of coatings [30, 31]. This is also attributed to the finer carbide particles and a less carbon loss during abrasive wear. The percentage decrease in CVL for WC-Co-Cr coating has been recorded as $98.94 \%$ at $30 \mathrm{~N}$, $99.3 \%$ at $40 \mathrm{~N}$ and $99.3 \%$ at $50 \mathrm{~N}$ as compared to the base metal. The reduction in the volume loss for $\mathrm{Al}_{2} \mathrm{O}_{3}+13 \mathrm{TiO}_{2}$ coated pins was recorded as $98.58 \%$ at $30 \mathrm{~N}, 98.89 \%$ at $40 \mathrm{~N}$ and $99.3 \%$ at $50 \mathrm{~N}$ against E52100 material. This is related to lower hardness and lower cohesion due to high porosity in alumina-titania coatings [32]. Finally, $\mathrm{Cr}_{3} \mathrm{C}_{2} \mathrm{NiCr}$ coating variant experienced $94.7 \%$ at $30 \mathrm{~N}, 90.75 \%$ at $40 \mathrm{~N}$ and $96.5 \%$ at $50 \mathrm{~N}$ as wear reduction, comparatively. This higher erosion is expected as the material removal occurred mainly by carbide particles fracture that involved crack initiation at a particlematrix interface which propagated to the surface of the coating. This phenomenon amplified with a higher porosity of the coating material being brittle in nature. Better wear resistance of WC-Co-Cr coating over other counterparts may be due to the better fracture as well as adhesive strength of the Co-Cr matrix with the carbides.

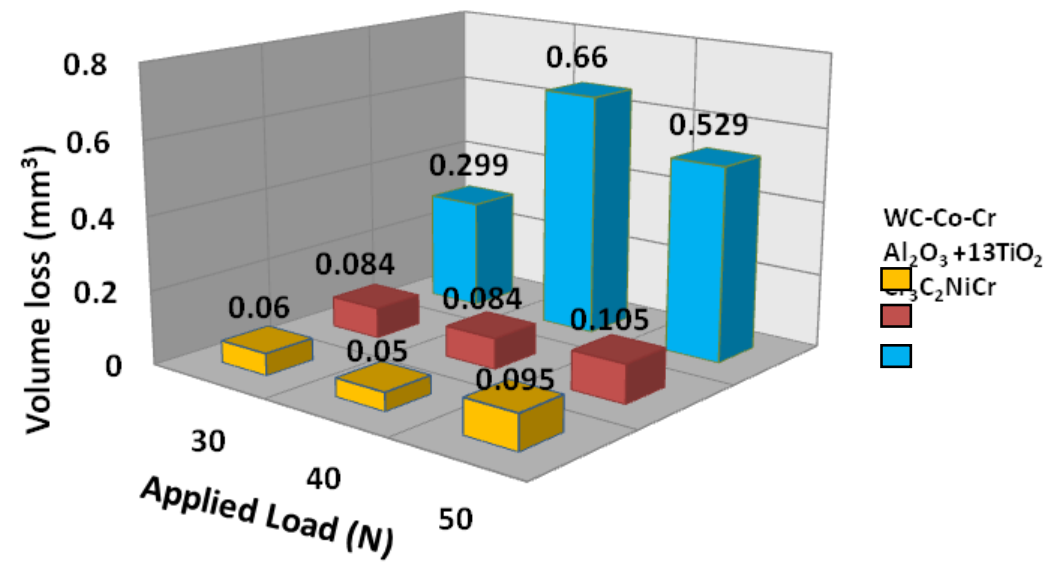

Fig. 8 Cumulative volume wear rate $\left(\mathrm{mm}^{3}\right)$ for coatings and uncoated E52100 at 30N, $40 \mathrm{~N}$, and $50 \mathrm{~N}$ 


\section{CONCLUSIONS}

This study aimed at investigating the effect of various plasma sprayed coatings on wear behavior of E52100 alloy steel under different loading conditions. SEM and XRD examinations were carried out to examine the wear mechanism that was witnessed to be influenced by various optimized coating and loading conditions. The following conclusions are drawn:

- The plasma sprayed WC-Co-Cr, $\mathrm{Cr}_{3} \mathrm{C}_{2} \mathrm{NiCr}, \mathrm{Al}_{2} \mathrm{O}_{3}+13 \mathrm{TiO}_{2}$ coatings developed on workpiece pins exhibited a notable decrease in volume loss of the material as compared to uncoated E52100 substrate. WC-Co-Cr coating turned out to be the best performer in terms of the lowest cumulative volume loss amid all the variants of coatings.

- The volume loss of thermally sprayed coated as well as uncoated E52100 specimen varied steeply with load applied.

- As a coating-substrate combination, WC-Co-Cr - E52100 had portrayed maximum wear resistance among all the three types of coatings followed by $\mathrm{Al}_{2} \mathrm{O}_{3}+13 \mathrm{TiO}_{2}$, whereas $\mathrm{Cr}_{3} \mathrm{C}_{2} \mathrm{NiCr}$ exhibited least wear resistance.

\section{REFERENCES}

1. Usta, I., Canoglu, S., 2003, Influence of ring traveler weight and coating on hairiness of acrylic and cotton yarns, Indian Journal of Fibre and Textile Research, 28(2), pp. 157-162.

2. Hess, M., 2019, A study on gross slip and fretting wear of contacts involving a power-law graded elastic halfspace, Facta Universitatis-Series Mechanical Engineering, 17(1), pp. 47-64.

3. Wang, Y., Jiang, S., Wang, M., Wang, S., Xiao, T.D., Strutt, P.R., 2000, Abrasive wear characteristic of plasma sprayed nanostructured alumina/titania coatings, Wear, 237(2), pp. 176-185.

4. Yilmaz, R., Kurt, A.O., Demir, A., Tatl, Z., 2007, Effects of $\mathrm{TiO}_{2}$ on the mechanical properties of the $\mathrm{Al}_{2} \mathrm{O}_{3}-\mathrm{TiO}_{2}$ plasma sprayed coating, Journal of the European Ceramic Society, 27(2-3), pp. 1319-1323.

5. Singh, G., Sidhu, S.S., Bains, P.S., Bhui, A.S., 2019, Improving microhardness and wear resistance of $316 L$ by $\mathrm{TiO}_{2}$ powder mixed electro-discharge treatment, Materials Research Express 6(8):086501.

6. Cukul, D., Beceren, Y., 2016, Yarn hairiness and the effect of surface characteristics of the ring traveler, Textile Research Journal, 86(15), pp. 1668-1674.

7. Y1lmaz, S., 2009, An evaluation of plasma-sprayed coatings based on $\mathrm{Al}_{2} \mathrm{O}_{3}$ and $\mathrm{Al}_{2} \mathrm{O}_{3}-13$ wt. \% $\mathrm{TiO}_{2}$ with bond coat on pure titanium substrate, Ceramics International, 35(5), pp. 2017-2022.

8. Clyne, T.W., Troughton, S.C., 2018, A review of recent work on discharge characteristics during plasma electrolytic oxidation of various metals, International Materials Reviews, 64(3), pp. 127-162.

9. Zhang, B., Dong, Q., Zhu, N., Ba, Z., Han, Y., Wang, Z., 2019, Microstructure and wear behaviors of plasmasprayed FeCrNiMoCBSi coating with nano-grain dispersed amorphous phase in reciprocating sliding contact, Tribology Transactions, 62(2), pp. 274-282.

10. Tao, S., Zhijian, Y., Xiaming, Z., Chuanxian, D., 2010, Sliding wear characteristics of plasma-sprayed $\mathrm{Al}_{2} \mathrm{O}_{3}$ and $\mathrm{Cr}_{2} \mathrm{O}_{3}$ coatings against copper alloy under severe conditions, Tribology International, 43(1-2), pp. 69-75.

11. Wang, L., Liu, S., Gou, J., Zhang, Q., Zhou, F., Wang, Y., Chu, R., 2019, Study on the wear resistance of graphene modified nanostructured $\mathrm{Al}_{2} \mathrm{O}_{3} / \mathrm{TiO}_{2}$ coatings, Applied Surface Science, 492(1), pp. 272-279.

12. Niu, B., Qiang, L., Zhang, J., Zhang, F., Hu, Y., Chen, W., Liang, A., 2018, Plasma sprayed $\alpha-\mathrm{Al}_{2} \mathrm{O}_{3}$ main phase coating using $\gamma-\mathrm{Al}_{2} \mathrm{O}_{3}$ powders, Surface Engineering, 35(9), pp. 801-808.

13. Rickerby, D.S., Winstone, M.R., 1992, Coatings for gas turbines, Material and Manufacturing Processes, 7(4), pp. 495-526.

14. Li, Q., Yuan, X., Xu, H., Song, P., Li, Q., Lu, K., Huang, T., Li, C., Lu, J., 2019, Microstructure and fracture toughness of in-situ nanocomposite coating by thermal spraying of $\mathrm{Ti}_{3} \mathrm{AlC} \mathrm{C}_{2} / \mathrm{Cu}$ powder, Ceramics International, 45(10), pp. 13119-13126.

15. Pawlowski, L., 1995, The Science and Engineering of Thermal Spray Coatings, John Wiley \& Sons, Inc.: Oxford, UK, pp. 626. 
16. Rhys, J., Thomas, N., 1990, Thermally sprayed coating systems for surface protection and clearance control applications in aero engines, Surface and Coatings Technology, 43(1), pp. 402-415.

17. Li, C.J., Guan-Jun, Y., Cheng-Xin, L., 2013, Development of particle interface bonding in thermal spray coatings: A review, Journal of Thermal Spray Technology, 22(2-3), pp. 192-206.

18. Giaglianonia, W.C., Cunha, M.A., Bergmanna, C.P., Fragassa, C., Pavlovic, A., 2018, Synthesis, characterization and application by $\mathrm{HVOF}$ of a $\mathrm{WC}-\mathrm{Co}-\mathrm{Cr} / \mathrm{NiCr}$ nanocomposite as protective coating against erosive wear, Tribology in Industry, 40(3), pp. 477-487.

19. Marques, A.S., Dalcin, R.L., Oliveira, L.F., Vitor-da-Silva, L.A., Santos, G.R., Alexandre-da-Silva, R., 2018, Comparative analysis of the friction and microstructural properties of $\mathrm{WC}-10 \mathrm{Co}-4 \mathrm{Cr}$ and $\mathrm{Cr} 3 \mathrm{C} 2-25 \mathrm{NiCr}$ coatings sprayed by high-velocity oxy-fuel (HVOF), American Journal of Materials Science, 8(3), pp. 51-57.

20. Dhakar, B., Chatterjee, S., Sabiruddin, K., 2016, Influence of process parameters on the formation of phases and mechanical properties of plasma sprayed $\mathrm{Al}_{2} \mathrm{O}_{3}-\mathrm{Cr}_{2} \mathrm{O}_{3}$ coatings, Materials Research Innovations, 21(6), pp. 367-376.

21. Manjunatha, S.S., Manjaiah, M., Basavarajappa, S., 2017, Predictive modelling of dry sliding wear in sealed plasma-sprayed Mo coating using response surface methodology, Tribology - Materials, Surfaces and Interfaces, 12(1), pp. 1-8.

22. Chatha, S.S., Sidhu, H.S., Sidhu B.S., 2012, Characterisation and corrosion-erosion behaviour of carbide based thermal spray coatings, Journal of Minerals and Materials Characterization and Engineering, 11(6), pp. 569-586.

23. Murthy, J.K.N., Venkataraman, B., 2006, Abrasive wear behavior of $\mathrm{WC}-\mathrm{Co}-\mathrm{Cr}$ and $\mathrm{Cr}_{3} \mathrm{C}_{2}-2 \mathrm{O}(\mathrm{NiCr})$ deposited by HVOF and detonation spray processes, Surface and Coatings Technology, 200(8), pp. 2642-2652.

24. Fujino, K., Shimotsuma, Y., 1955, Studies on spinning rings and travelers, Textile Research Journal, 25(9), pp. $799-811$.

25. Lingzhong, D., Chuanbing, H., 2011, Preparation and Wear Performance of $\mathrm{NiCr} / \mathrm{Cr}_{3} \mathrm{C}_{2}-\mathrm{NiCr} / \mathrm{hBN}$ Plasma Sprayed Composite Coating, Surface and Coatings Technology, 205(12), pp. 3722-3728.

26. Karimi, A., Verdon, C., Barbezat, G., 1993, Microstructure and hydroabrasive wear behaviour of high velocity oxy-fuel thermally sprayed WC-Co (Cr) coatings, Surface and Coating Technology, 57(1), pp. 81-89.

27. Mahajan, A., Sidhu, S.S., 2018, Enhancing biocompatibility of Co-Cr alloy implants via electrical discharge process, Materials Technology, 33(8), pp. 524-531.

28. Bagde, P., Sapate, S.G., Khatirkar, R.K., Vashishtha, N., 2018, Friction and abrasive wear behaviour of $\mathrm{Al}_{2} \mathrm{O}_{3}-$ $13 \mathrm{TiO}_{2}$ and $\mathrm{Al}_{2} \mathrm{O}_{3}-13 \mathrm{TiO}_{2}+\mathrm{Ni}$ Graphite coatings, Tribology International, 121(1), 353-372.

29. Li, Z., Wei, M., Xiao, K., Bai, Z., Xue, W., Dong, C., Wei, D., Li, X., 2019, Microhardness and wear resistance of $\mathrm{Al}_{2} \mathrm{O}_{3}-\mathrm{TiB}_{2}-\mathrm{TiC}$ ceramic coatings on carbon steel fabricated by laser cladding, Ceramics International, 45(1), pp. $115-121$.

30. Mahajan, A., Sidhu, S.S., 2019, Potential of electrical discharge treatment to enhance the in vitro cytocompatibility and tribological performance of $\mathrm{Co}-\mathrm{Cr}$ implant, Journal of Materials Research, 34(16), pp. 2837-2847.

31. Nasiri-Vatan, H., Adabi, M., 2017, Investigation of wear and corrosion resistance of nanocomposite coating formed on AZ31B Mg alloy by plasma electrolytic oxidation, Transactions of the IMF, 95(6), pp. 308-315.

32. Pinzon, A.V., Urrego, K.J., Gonzalez-Hernandez, A., Ortiz, M.R., Galvis, F.V., 2018, Corrosion protection of carbon steel by alumina-titania ceramic coatings used for industrial applications, Ceramics International, 44(17), pp. 21765-21773. 